\title{
Potential Application of Drosophila melanogaster as a Model Organism in COVID-19-Related Research
}

\author{
Firzan Nainu ${ }^{1 *}$, Dini Rahmatika ${ }^{2}$, Talha Bin Emran ${ }^{3}$ and Harapan Harapan ${ }^{4,5,6}$ \\ 1 Faculty of Pharmacy, Hasanuddin University, Makassar, Indonesia, ${ }^{2}$ Department of Pharmaceutical Science, Faculty of \\ Mathematics and Natural Sciences, Lambung Mangkurat University, Banjar Baru, Indonesia, ${ }^{3}$ Department of Pharmacy, \\ BGC Trust University Bangladesh, Chittagong, Bangladesh, ${ }^{4}$ Medical Research Unit, School of Medicine, Universitas Syiah \\ Kuala, Banda Aceh, Indonesia, 5 Tropical Disease Centre, School of Medicine, Universitas Syiah Kuala, Banda Aceh, \\ Indonesia, ${ }^{6}$ Department of Microbiology, School of Medicine, Universitas Syiah Kuala, Banda Aceh, Indonesia
}

\section{OPEN ACCESS}

Edited by:

Salvatore Salomone,

University of Catania, Italy

Reviewed by:

Amy Adamson,

University of North Carolina at Greensboro, United States

*Correspondence:

Firzan Nainu

firzannainu@unhas.ac.id

Specialty section:

This article was submitted to

Experimental Pharmacology

and Drug Discovery,

a section of the journal

Frontiers in Pharmacology

Received: 29 July 2020

Accepted: 20 August 2020

Published: 04 September 2020

Citation:

Nainu F, Rahmatika D, Emran TB and Harapan $\mathrm{H}$ (2020) Potential

Application of Drosophila

melanogaster as a Model Organism in

COVID-19-Related Research.

Front. Pharmacol. 11:588561.

doi: 10.3389/fphar.2020.588561
Keywords: SARS-CoV 2, COVID-19, fruit fly, model organism, RNAi screening, in vivo, in vitro

Since December 2019, the severe acute respiratory syndrome coronavirus 2 (SARS-CoV-2) has been reported to cause a life-threatening malady with multi-spectrum symptoms, called coronavirus disease 2019 (COVID-19). As of August 19, 2020, the disease has spread to more than 225 countries and infected over 20 million people worldwide (Dong et al., 2020), causing upheavals in many aspects of human life (Harapan et al., 2020). At present, much effort has been given to define the clinical characteristics of COVID-19 patients and to discover safe and efficacious vaccines and therapeutics to combat SARS-CoV-2 infection (Dhama et al., 2020). Yet, much more data such as the characteristics of viral genes responsible in the infectivity, factors accountable in the host susceptibility to SARS-CoV-2 infection, viral pathogenesis and the subsequent protective role of host immune responses, and the culmination of host-virus interaction into different types of symptoms in the COVID-19 patients, remains to be fully elucidated. This knowledge is crucial to improve the prevention efforts and treatment strategies needed to manage the spread of COVID-19.

In the presence of ethical constraints to perform explorative research on humans, using proper model organisms to address the above unrequited yet essential aspects of COVID-19 is urgently required. With the aid of suitable animal models, the pharmacodynamics and pharmacokinetic profiles as well as the safety of novel pharmaceuticals to treat COVID-19 can be investigated in a relatively easier, safer, and economical way. Also, identification of the main pathways for COVID19 pathophysiology that may provide insights for disease prevention and/or treatment can be accomplished in relative terms where possible. Already, several animal models have been used to study SARS-CoV-2 infection. For instance, a study using rhesus macaque, a non-human primate with close phylogenetic proximity to humans, revealed the significance of immunity to protect the host from COVID-19 reinfection (Bao et al., 2020a). While non-human primates represent the strongest ally to solve some COVID-19 enigmatic problems in vivo, it is important to note that studies using this model were mostly performed using small numbers of animals in their experiments (e.g., as low as one or two rhesus macaques per group) due to the ethical concerns 
and animal scarcity. Therefore, the results should be interpreted with caution. To address this issue, several alternative animal models were proposed (Takayama, 2020; Yuan et al., 2020).

Based on its highly characterized immune system, rapid breeding cycle, simplicity, and availability of research tools, mice (Mus musculus) have been regarded as one of the most common animal models to demonstrate the pathological properties of viruses and their consequences on the host respiratory system. However, the spike (S) protein of SARSCoV-2 has been suggested to have an insufficient affinity for the murine ACE2 entry receptor (Wan et al., 2020), which may explain the limitation to obtain a productive infective state in this model. Nevertheless, transgenic mice with endogenous expression of human ACE2 has been developed to address this issue (Bao et al., 2020b). Unfortunately, during the times of COVID-19 pandemic, the low availability of hACE2 transgenic mice might be difficult to compensate for the increasing demand for such a model, thus restraining its extensive use in COVID-19 research (Soldatov et al., 2020).

Since its discovery, some basic information about COVID-19 and its causative agent, SARS-CoV-2, has been rapidly revealed with animal models (Takayama, 2020; Yuan et al., 2020). In this article, we propose using the fruit fly Drosophila melanogaster as one of the promising model organisms to unveil specific COVID-19-related questions based on several considerations. First, this invertebrate model has been widely used to investigate

TABLE 1 | List of human viruses studied using Drosophila model system.

\begin{tabular}{|c|c|c|c|c|c|}
\hline $\begin{array}{l}\text { Genome } \\
\text { type }\end{array}$ & Virus & Diseases in human & $\begin{array}{l}\text { Experimental systems used in } \\
\text { Drosophila }\end{array}$ & Lessons learned from Drosophila model & Refs \\
\hline $\begin{array}{l}\text { ssRNA } \\
\text { (positive } \\
\text { sense } \\
\text { with RT) }\end{array}$ & $\begin{array}{l}\text { Human immune- } \\
\text { deficiency } \\
\text { virus (HIV)-1 }\end{array}$ & $\begin{array}{l}\text { Acquired immune } \\
\text { deficiency syndrome } \\
\text { (AIDS) }\end{array}$ & $\begin{array}{l}\text { In vitro (transfected cell culture), } \\
\text { In vivo (transgenic fly to express } \\
\text { viral proteins) }\end{array}$ & $\begin{array}{l}\text { Inhibition of Toll pathway and induction of JNK pathway } \\
\text { by HIV-1 Vpu are occurred in tissue-dependent manner }\end{array}$ & $\begin{array}{l}\text { (Leulier et al., } \\
\text { 2003; Marchal } \\
\text { et al., 2012) }\end{array}$ \\
\hline \multirow[t]{4}{*}{$\begin{array}{l}\text { ssRNA } \\
\text { (positive } \\
\text { sense) }\end{array}$} & $\begin{array}{l}\text { Dengue virus } \\
\text { (DENV) }\end{array}$ & $\begin{array}{l}\text { Dengue hemorrhagic } \\
\text { fever (DHF) and } \\
\text { dengue shock } \\
\text { syndrome }\end{array}$ & $\begin{array}{l}\text { In vitro genome-wide RNAi } \\
\text { screen: } \\
\text { Drosophila cell culture, infected } \\
\text { with DENV serotypes } 1-4\end{array}$ & $\begin{array}{l}\text {-The significance of RNAi to control DENV infection } \\
\text {-Several host factors have been found to be important in } \\
\text { the infection control. These factors are suggested to be } \\
\text { conserved between Drosophila and humans. }\end{array}$ & $\begin{array}{l}\text { (Sessions et al., } \\
\text { 2009; Mukherjee } \\
\text { and Hanley, } \\
\text { 2010) }\end{array}$ \\
\hline & $\begin{array}{l}\text { severe acute } \\
\text { respiratory } \\
\text { syndrome } \\
\text { coronavirus } \\
\text { (SARS-CoV) }\end{array}$ & Atypical pneumonia & $\begin{array}{l}\text { In vivo (transgenic fly to express } \\
\text { viral proteins) }\end{array}$ & $\begin{array}{l}\text { Possible interactions between the SARS-CoV } 3 a \text { and M } \\
\text { with cytochrome c and the AKT pathway of the host, } \\
\text { respectively }\end{array}$ & $\begin{array}{l}\text { (Wong et al., } \\
\text { 2005; Chan } \\
\text { et al., 2007) }\end{array}$ \\
\hline & $\begin{array}{l}\text { Sindbis virus } \\
\text { (SINV) }\end{array}$ & Sindbis fever & $\begin{array}{l}\text { In vitro and in vivo (natural } \\
\text { infection) }\end{array}$ & $\begin{array}{l}\text { The role of NRAMP family proteins in SINV entry into } \\
\text { Drosophila (and mammalian cells) and the importance of } \\
\text { ERK pathway in the intestinal immunity of Drosophila (and } \\
\text { mosquito) }\end{array}$ & $\begin{array}{l}\text { (Rose et al., } \\
\text { 2011; Xu et al., } \\
\text { 2013) }\end{array}$ \\
\hline & $\begin{array}{l}\text { West Nile virus } \\
\text { (WNV) }\end{array}$ & $\begin{array}{l}\text { West Nile fever } \\
\text { (including meningitis } \\
\text { and } \\
\text { encephalitis) }\end{array}$ & $\begin{array}{l}\text { In vitro and in vivo (natural } \\
\text { infection) }\end{array}$ & $\begin{array}{l}\text { Possible suppression of RNAi in Drosophila (and } \\
\text { mammalian cells) by non-coding WNV RNA }\end{array}$ & $\begin{array}{l}\text { (Chotkowski } \\
\text { et al., 2008; } \\
\text { Schnettler et al., } \\
\text { 2012) }\end{array}$ \\
\hline \multirow[t]{2}{*}{$\begin{array}{l}\text { ssRNA } \\
\text { (negative } \\
\text { sense) }\end{array}$} & $\begin{array}{l}\text { Influenza A virus } \\
\text { (IAV) }\end{array}$ & Flu pandemics & $\begin{array}{l}\text { In vitro genome-wide RNAi } \\
\text { screen: Drosophila cell culture, } \\
\text { infected with a genetically } \\
\text { modified Influenza A virus }\end{array}$ & $\begin{array}{l}\text { Several host factors have been found to be important in } \\
\text { influenza virus replication and host cell programming. } \\
\text { These factors are suggested to be conserved between } \\
\text { Drosophila and humans. }\end{array}$ & (Hao et al., 2008) \\
\hline & $\begin{array}{l}\text { Vesicular } \\
\text { stomatitis virus } \\
\text { (VSV) }\end{array}$ & $\begin{array}{l}\text { Flu-like illness; } \\
\text { oncolytic virus }\end{array}$ & $\begin{array}{l}\text { In vitro and in vivo (natural } \\
\text { infection) }\end{array}$ & $\begin{array}{l}\text { The role of Drosophila Toll- } 7 \text { in autophagy induction (in a } \\
\text { manner independent on the NF- } \mathrm{KB} \text { activity) to limit VSV } \\
\text { infection. This is similar to TLR7 role in mammals }\end{array}$ & $\begin{array}{l}\text { (Nakamoto et al., } \\
\text { 2012) }\end{array}$ \\
\hline \multirow[t]{2}{*}{ dsDNA } & $\begin{array}{l}\text { Epstein-Barr virus } \\
\text { (EBV) }\end{array}$ & $\begin{array}{l}\text { Infectious } \\
\text { mononucleosis, } \\
\text { several types of } \\
\text { cancer, and multiple } \\
\text { sclerosis }\end{array}$ & $\begin{array}{l}\text { In vivo (transgenic fly to express } \\
\text { viral proteins) }\end{array}$ & $\begin{array}{l}\text { Identification of relevant human tumor suppressors that } \\
\text { are targeted by the BRLF1 of EBV to induce } \\
\text { tumorigenesis }\end{array}$ & $\begin{array}{l}\text { (Adamson et al., } \\
\text { 2005; Adamson } \\
\text { and LaJeunesse, } \\
\text { 2012) }\end{array}$ \\
\hline & $\begin{array}{l}\text { Human } \\
\text { cytomega-lovirus } \\
\text { (HCMV) }\end{array}$ & Birth defects & $\begin{array}{l}\text { In vivo (transgenic fly to express } \\
\text { viral proteins) }\end{array}$ & Potential inhibition of embryogenesis by viral proteins & $\begin{array}{l}\text { (Steinberg et al., } \\
\text { 2008) }\end{array}$ \\
\hline \multirow[t]{2}{*}{ dsDNA } & $\begin{array}{l}\text { Simian virus (SV) } \\
40\end{array}$ & $\begin{array}{l}\text { Undecided } \\
\text { (oncogenic role in } \\
\text { tumor remains } \\
\text { questionable) }\end{array}$ & $\begin{array}{l}\text { In vivo (transgenic fly to express } \\
\text { viral proteins) }\end{array}$ & $\begin{array}{l}\text { Possible mechanism of oncogenesis by the small tumor } \\
\text { antigen (ST) of SV40 }\end{array}$ & $\begin{array}{l}\text { (Kotadia et al., } \\
\text { 2008) }\end{array}$ \\
\hline & $\begin{array}{l}\text { Vaccinia virus } \\
\text { (VACV) }\end{array}$ & $\begin{array}{l}\text { Rash and fever. Used } \\
\text { as a vaccine for } \\
\text { smallpox prevention }\end{array}$ & $\begin{array}{l}\text { In vitro and in vivo (natural } \\
\text { infection), } \\
\text { In vivo (transgenic fly to express } \\
\text { viral proteins) }\end{array}$ & Identification of host factors required viral entry & $\begin{array}{l}\text { (Moser et al., } \\
\text { 2010) }\end{array}$ \\
\hline
\end{tabular}

ss, single-stranded; ds, double stranded; RT, reverse transcriptase; RNAi, RNA interference. 
the molecular properties and cellular functions of certain protein components of human viruses in the in vitro and in vivo platforms (Table 1) (Hughes et al., 2012; Panayidou et al., 2014) and to provide basic understandings on the conserved host antiviral immunity in the metazoan species ( $\mathrm{Xu}$ and Cherry, 2014; Nainu et al., 2017). Among other aspects, the identification of host cellular factors required for SARS-CoV-2 replication is one of the important pillars that could provide valuable insights into novel targets for anti-COVID-19 therapy. An in vitro genome-wide RNA interference screen using $D$. melanogaster cells demonstrated the value of this approach to identify cellular host factors required for the replication of influenza $A$ and dengue viruses (Hao et al., 2008; Sessions et al., 2009). In addition to that, a binary GAL4/UAS gene expression system in Drosophila was successfully used as an economical, rapid, and efficient in vivo platform to characterize the apoptotic role of two SARS-CoV proteins, protein 3a and M (Wong et al., 2005; Chan et al., 2007). The two-component GAL4/UAS system is comprised of the Gal4 gene, encoding the yeast transcription activator protein Gal4, and the UAS (Upstream Activation Sequence), a site to which GAL4 binds to activate the transcription of the transgene of interest downstream of the UAS (Brand and Perrimon, 1993). Using a similar approach, it would be reasonably feasible to closely study the function of SARS-CoV-2 genes in the context of whole Drosophila tissues in vivo or at different developmental stages.

Second, D. melanogaster retains many essential characteristics required in a model organism allowing for a straightforward, robust, and in-depth study of viral gene function in the in vitro and in vivo settings. Despite size differences, Drosophila shares around $75 \%$ genetic similarity with humans (Pandey and Nichols, 2011), allowing a robust genetically tractable approach to investigate the conserved function of viral proteins on host cells and host factor(s) required for a reproductive infection. With its relatively simple genetics, the fruit fly is highly amenable for possible genetic modifications, as demonstrated by an improved list of transgenic and mutant lines, including those designed using the latest CRISPR-based method applicable for human infectious disease models (Pandey and Nichols, 2011; Ugur et al., 2016). Moreover, D. melanogaster can be maintained easily and inexpensively in the laboratory, making it convenient to be used by researchers with limited funding (Pandey and Nichols, 2011). Its rapid propagation and short lifespan (approximately one month in length) (Pandey and Nichols, 2011) might serve as beneficial experimental traits that help reduce time to obtain results, which is certainly essential during the outbreak.

Undoubtedly, despite its numerous advantages, there exist several limitations that may pose a challenge to use Drosophila as a host model in human virus research. Of all, physiological and genetic differences between Drosophila and humans are two of the most anticipated constraints (Hughes et al., 2012; Panayidou et al., 2014). Nevertheless, it is worth noting that such limitations are typical for other animal models. Hence, a better way to study human viruses is to verify findings in Drosophila to other mammalian models as well as in humans. Alternatively,
Drosophila can also be used as a complementary model system, together with other animal models, to understand antiviral immunity against COVID-19. For example, while the lack of adaptive immune responses in Drosophila has prevented its use in vaccine-related research, some of the human-homologous innate antiviral immunity had been first discovered or later confirmed in Drosophila (Xu and Cherry, 2014; Nainu et al., 2015), suggesting that fly research may reveal important insights in the innate immune responses against SARS-CoV-2. Besides, even though some mammalian viruses need to be modified before infection experiments in Drosophila, some of them can naturally enter Drosophila cells and are immediately detected by Drosophila immune factors and/or cells (see Table 1). This suggests the conserved infection mechanism(s) and innate immune responses between fruit flies and mammals. With this approach, we might provide some additional answers to remaining COVID-19-related questions in a reasonable, systematic, and economical manner.

Currently, D. melanogaster has been a leading model system for studying biochemical and biological aspects of human viruses and their pathogenic consequences on host cells (Hughes et al., 2012; Panayidou et al., 2014). The availability of sophisticated molecular tools for in vitro and in vivo experiments (Pandey and Nichols, 2011; Ugur et al., 2016), followed by the versatility of the model system and feasibility of research using human viruses (Hughes et al., 2012; Panayidou et al., 2014) are some of the powerful features in Drosophila that shall be beneficial to explore biological events in a precise detail that may be difficult to overcome using higher animal models. In the long run, we believe that $D$. melanogaster will serve as a convenient model organism for COVID-19-related research. For example, this model organism might help us to uncover factors related to host susceptibility to SARS-CoV-2 infection, as demonstrated in the case of influenza A and dengue viruses (Hao et al., 2008; Sessions et al., 2009), and whether those factors are clinically responsible in the human susceptibility to SARS-CoV-2. Alternatively, one may try to address the mechanistic basis of host innate immune activation in response to SARS-CoV-2 infection and whether disruptions in these mechanisms may yield different outcomes in the infected hosts. Certainly, with the right questions to ask, D. melanogaster would be a potential ally in the fight against COVID-19.

\section{AUTHOR CONTRIBUTIONS}

FN and DR designed and drafted the manuscript. FN, HH, and TE revised the manuscript critically for important intellectual content. All authors contributed to the article and approved the submitted version.

\section{ACKNOWLEDGMENTS}

We would like to offer our gratitude to the Frontiers Media COVID-19 Access fund for publication financial support. 


\section{REFERENCES}

Adamson, A., and LaJeunesse, D. (2012). A study of Epstein-Barr Virus BRLF1 activity in a Drosophila model system. Sci. World J. 2012, 347597. doi: 10.1100/ 2012/347597

Adamson, A. L., Wright, N., and LaJeunesse, D. R. (2005). Modeling early EpsteinBarr virus infection in Drosophila melanogaster: the BZLF1 protein. Genetics 171 (3), 1125-1135. doi: 10.1534/genetics.105.042572

Bao, L., Deng, W., Gao, H., Xiao, C., Liu, J., Xue, J., et al. (2020a). Reinfection could not occur in SARS-CoV-2 infected rhesus macaques. bioRxiv 2020.2003.2013.990226. doi: 10.1101/2020.03.13.990226

Bao, L., Deng, W., Huang, B., Gao, H., Liu, J., Ren, L., et al. (2020b). The pathogenicity of SARS-CoV-2 in hACE2 transgenic mice. Nature 583, 830833. doi: $10.1101 / 2020.02 .07 .939389$

Brand, A. H., and Perrimon, N. (1993). Targeted gene expression as a means of altering cell fates and generating dominant phenotypes. Development 118 (2), 401-415.

Chan, C. M., Ma, C. W., Chan, W. Y., and Chan, H. Y. (2007). The SARS-coronavirus membrane protein induces apoptosis through modulating the Akt survival pathway. Arch. Biochem. Biophys. 459 (2), 197-207. doi: 10.1016/j.abb.2007.01.012

Chotkowski, H. L., Ciota, A. T., Jia, Y., Puig-Basagoiti, F., Kramer, L. D., Shi, P.-Y., et al. (2008). West Nile virus infection of Drosophila melanogaster induces a protective RNAi response. Virology 377 (1), 197-206. doi: 10.1016/j.virol.2008.04.021

Dhama, K., Khan, S., Tiwari, R., Sircar, S., Bhat, S., Malik, Y. S., et al. (2020). Coronavirus Disease 2019-COVID-19. Clin. Microbiol. Rev. 33 (4), e00028e00020. doi: 10.1128/CMR.00028-20

Dong, E., Du, H., and Gardner, L. (2020). An interactive web-based dashboard to track COVID-19 in real time. Lancet Infect. Dis. 20, 533-534 doi: 10.1016/ S1473-3099(20)30120-1

Hao, L., Sakurai, A., Watanabe, T., Sorensen, E., Nidom, C. A., Newton, M. A., et al. (2008). Drosophila RNAi screen identifies host genes important for influenza virus replication. Nature 454 (7206), 890-893. doi: 10.1038/nature07151

Harapan, H., Itoh, N., Yufika, A., Winardi, W., Keam, S., Te, H., et al. (2020). Coronavirus disease 2019 (COVID-19): A literature review. J. Infect. Public Health 13 (5), 667-673. doi: 10.1016/j.jiph.2020.03.019

Hughes, T. T., Allen, A. L., Bardin, J. E., Christian, M. N., Daimon, K., Dozier, K. D., et al. (2012). Drosophila as a genetic model for studying pathogenic human viruses. Virology 423 (1), 1-5. doi: 10.1016/j.virol.2011.11.016

Kotadia, S., Kao, L. R., Comerford, S. A., Jones, R. T., Hammer, R. E., and Megraw, T. L. (2008). PP2A-dependent disruption of centrosome replication and cytoskeleton organization in Drosophila by SV40 small tumor antigen. Oncogene 27 (49), 6334-6346. doi: 10.1038/onc.2008.254

Leulier, F., Marchal, C., Miletich, I., Limbourg-Bouchon, B., Benarous, R., and Lemaitre, B. (2003). Directed expression of the HIV-1 accessory protein Vpu in Drosophila fat-body cells inhibits Toll-dependent immune responses. EMBO Rep. 4 (10), 976-981. doi: 10.1038/sj.embor.embor936

Marchal, C., Vinatier, G., Sanial, M., Plessis, A., Pret, A. M., Limbourg-Bouchon, B., et al. (2012). The HIV-1 Vpu protein induces apoptosis in Drosophila via activation of JNK signaling. PLoS One 7 (3), e34310. doi: 10.1371/journal.pone.0034310

Moser, T. S., Sabin, L. R., and Cherry, S. (2010). RNAi screening for host factors involved in Vaccinia virus infection using Drosophila cells. J. Vis. Exp. 42 (42), e2137. doi: 10.3791/2137

Mukherjee, S., and Hanley, K. A. (2010). RNA interference modulates replication of dengue virus in Drosophila melanogaster cells. BMC Microbiol. 10, 127. doi: 10.1186/1471-2180-10-127

Nainu, F., Tanaka, Y., Shiratsuchi, A., and Nakanishi, Y. (2015). Protection of insects against viral infection by apoptosis-dependent phagocytosis. J. Immunol. 195 (12), 5696-5706. doi: 10.4049/jimmunol.1500613

Nainu, F., Shiratsuchi, A., and Nakanishi, Y. (2017). Induction of apoptosis and subsequent phagocytosis of virus-infected cells as an antiviral mechanism. Front. Immunol. 8 (1220), 1-11. doi: 10.3389/fimmu.2017.01220
Nakamoto, M., Moy, R. H., Xu, J., Bambina, S., Yasunaga, A., Shelly, S. S., et al. (2012). Virus recognition by Toll-7 activates antiviral autophagy in Drosophila. Immunity 36 (4), 658-667. doi: 10.1016/j.immuni.2012.03.003

Panayidou, S., Ioannidou, E., and Apidianakis, Y. (2014). Human pathogenic bacteria, fungi, and viruses in Drosophila: disease modeling, lessons, and shortcomings. Virulence 5 (2), 253-269. doi: 10.4161/viru.27524

Pandey, U. B., and Nichols, C. D. (2011). Human disease models in Drosophila melanogaster and the role of the fly in therapeutic drug discovery. Pharmacol. Rev. 63 (2), 411-436. doi: 10.1124/pr.110.003293

Rose, P. P., Hanna, S. L., Spiridigliozzi, A., Wannissorn, N., Beiting, D. P., Ross, S. R., et al. (2011). Natural resistance-associated macrophage protein is a cellular receptor for sindbis virus in both insect and mammalian hosts. Cell Host Microbe 10 (2), 97-104. doi: 10.1016/j.chom.2011.06.009

Schnettler, E., Sterken, M. G., Leung, J. Y., Metz, S. W., Geertsema, C., Goldbach, R. W., et al. (2012). Noncoding flavivirus RNA displays RNA interference suppressor activity in insect and mammalian cells. J. Virol. 86 (24), 1348613500. doi: 10.1128/JVI.01104-12

Sessions, O. M., Barrows, N. J., Souza-Neto, J. A., Robinson, T. J., Hershey, C. L., Rodgers, M. A., et al. (2009). Discovery of insect and human dengue virus host factors. Nature 458 (7241), 1047-1050. doi: 10.1038/nature07967

Soldatov, V. O., Kubekina, M. V., Silaeva, Y. Y., Bruter, A. V., and Deykin, A. V. (2020). On the way from SARS-CoV-sensitive mice to murine COVID-19 model. Res. Results Pharmacol. 6 (2), 1-7. doi: 10.3897/rrpharmacology.6.53633

Steinberg, R., Shemer-Avni, Y., Adler, N., and Neuman-Silberberg, S. (2008). Human cytomegalovirus immediate-early-gene expression disrupts embryogenesis in transgenic Drosophila. Transgenic Res. 17 (1), 105-119. doi: 10.1007/s11248007-9136-5

Takayama, K. (2020). In vitro and animal models for SARS-CoV-2 research. Trends Pharmacol. Sci. 41 (8), 513-517. doi: 10.1016/j.tips.2020.05.005

Ugur, B., Chen, K., and Bellen, H. J. (2016). Drosophila tools and assays for the study of human diseases. Dis. Model Mech. 9 (3), 235-244. doi: 10.1242/ dmm.023762

Wan, Y., Shang, J., Graham, R., Baric, R. S., and Li, F. (2020). Receptor recognition by the novel coronavirus from Wuhan: an analysis based on decade-long structural studies of SARS coronavirus. J. Virol. 94 (7), e00127-e00120. doi: 10.1128/JVI.00127-20

Wong, S. L. A., Chen, Y., Chan, C. M., Chan, C. S. M., Chan, P. K. S., Chui, Y. L., et al. (2005). In vivo functional characterization of the SARS-Coronavirus 3 a protein in Drosophila. Biochem. Biophys. Res. Commun. 337 (2), 720-729. doi: 10.1016/j.bbrc.2005.09.098

$\mathrm{Xu}$, J., and Cherry, S. (2014). Viruses and antiviral immunity in Drosophila. Dev. Comp. Immunol. 42 (1), 67-84. doi: 10.1016/j.dci.2013.05.002

Xu, J., Hopkins, K., Sabin, L., Yasunaga, A., Subramanian, H., Lamborn, I., et al. (2013). ERK signaling couples nutrient status to antiviral defense in the insect gut. Proc. Natl. Acad. Sci. U. S. A. 110 (37), 15025-15030. doi: 10.1073/pnas. 1303193110

Yuan, L., Tang, Q., Cheng, T., and Xia, N. (2020). Animal models for emerging coronavirus: progress and new insights. Emerg. Microbes Infect. 9 (1), 949-961. doi: $10.1080 / 22221751.2020 .1764871$

Conflict of Interest: The authors declare that the research was conducted in the absence of any commercial or financial relationships that could be construed as a potential conflict of interest.

Copyright (c) 2020 Nainu, Rahmatika, Emran and Harapan. This is an open-access article distributed under the terms of the Creative Commons Attribution License (CC BY). The use, distribution or reproduction in other forums is permitted, provided the original author(s) and the copyright owner(s) are credited and that the original publication in this journal is cited, in accordance with accepted academic practice. No use, distribution or reproduction is permitted which does not comply with these terms. 